www.asianjournalofmycology.org Article

Doi 10.5943/ajom/2/1/12

\title{
Morphology and phylogeny of Yunnanomyces phoenicis sp. nov. (Sympoventuriaceae) from Thailand
}

\author{
Zhang $\mathrm{SN}^{1,2,3}$, Liu $\mathrm{JK}^{3,4}$, Jones $\mathrm{EBG}^{5}$ and Cheewangkoon $\mathrm{R}^{1^{*}}$ \\ ${ }^{1}$ Department of Entomology and Plant Pathology, Faculty of Agriculture, Chiang Mai University, Chiang Mai 50200, \\ Thailand \\ ${ }^{2}$ Center of Excellence in Fungal Research, Mae Fah Luang University, Chiang Rai 57100, Thailand \\ ${ }^{3}$ Guizhou Key Laboratory of Agricultural Biotechnology, Guizhou Academy of Agricultural Science, Guiyang 550006, \\ Guizhou, P.R. China \\ ${ }^{4}$ School of Life Science and Technology, University of Electronic Science and Technology of China, Chengdu 611731, \\ P.R. China \\ ${ }^{5}$ Deptartment of Botany and Microbiology, College of Science, King Saud University, P.O Box 2455 Riyadh 11451, \\ Kingdom of Saudi Arabia
}

Zhang SN, Liu JK, Jones EBG, Cheewangkoon R 2019 - Morphology and Phylogeny of Yunnanomyces phoenicis sp. nov. (Sympoventuriaceae) from Thailand. Asian Journal of Mycology 2(1), 213-221, Doi 10.5943/ajom/2/1/12

\section{Abstract}

A new hyphomycetous species, associated with monocotyledonous Phoenix paludosa (mangrove date palm) was isolated and is introduced in this study. Multi-gene (LSU, SSU and RPB2) phylogenetic analyses showed that the new taxon clustered together with Yunnanomyces pandanicola and formed a well-supported clade within the family Sympoventuriaceae (Venturiales). The taxon is characterized by it semi-macronematous conidiophores, reduced to conidiogenous cells, and bears globose to broadly ellipsoidal, muriform conidia. It is morphologically similar to Yunnanomyces pandanicola, but differs from the latter in its reduced conidiophores and larger, brown conidia. The phylogenetic result also confirms that this fungus is a distinct species of Yunnanomyces. Therefore, Yunnanomyces phoenicis sp. nov. is introduced herein, and its morphological features, sporulation in culture are described and illustrated, as well as its phylogenetic placement is provided.

Key words - 1 new taxon - Asexual - Dothideomycetes - Muriform conidia - Taxonomy

\section{Introduction}

Plant tissues harbour vast heterotrophic microfungi which exhibit parasitic, saprobic or symbiotic life strategies. The family Sympoventuriaceae Yin. Zhang, C.L. Schoch \& K.D. Hyde (Zhang et al. 2011) is typified by Sympoventuria Crous \& Seifert (Crous et al. 2007), and comprising a group of plant-pathogens or -saprobes, as well as oligotrophic saprobes and some opportunistic species causing infections in vertebrates (Machouart et al. 2014). Phylogenetic analysis indicated that Sympoventuriaceae and Venturiaceae E. Müll. \& Arx ex M.E. Barr are sister groups; belonging to the order Venturiales within Dothideomycetes (Zhang et al. 2011, Hyde et al. 2013, Liu et al. 2017). Currently, seven genera: Clavatispora Boonmee \& K.D. Hyde (Boonmee et al. 2014), Mycosisymbrium (Pratibha \& Prabhugaonkar 2016), Ochroconis (Machouart et al. 2014), Sympoventuria, Veronaeopsis Arzanlou \& Crous (Arzanlou et al. 2007), Verruconis (Samerpitak et 
al. 2014), Yunnanomyces Tibpromma \& K.D. Hyde (Tibpromma et al. 2018), as well as species from Fusicladium Bonord (Machouart et al. 2014), Neocoleroa Petr. (Johnston \& Park 2016) and Scolecobasidium E.V. Abbott (Machouart et al. 2014) are referred to the family Sympoventuriaceae based on multi-gene phylogeny.

Asexual morphs of Sympoventuriaceae are known as fusicladium-like, sympodiella-like, Veronaeopsis (Zhang et al. 2011), trichocladium-like (Boonmee et al. 2014) and Yunnanomyces (Tibpromma et al. 2018). However, Yunnanomyces can be easily distinguished from other asexual morphs by the globose to broadly oval, yellow to brown, muriform conidia. We are carrying out a fungal diversity survey on palms and several new taxa have been described from Thailand (Konta et al. 2016a, b, c, 2017, Wanasinghe et al. 2018, Zhang et al 2018, 2019a, b). In this study, a new asexual fungus Yunnanomyces phoenicis is introduced. Its morphology fits well with the genus Yunnanomyces, but can be distinguished from the type $Y$. pandanicola by having reduced conidiophores and larger, brown conidia; the phylogenetic results also confirm its distinction. A detailed description and illustration are provided.

\section{Materials \& Methods}

\section{Specimens collection, examination and single spores isolation}

Decaying rachides and leaves of mangrove date palm Phoenix paludosa were collected from Ranong and Chanthaburi provinces in Thailand. Specimens were sorted and placed into plastic bags in the field along with the collecting information. Fungal fruiting bodies were observed using Motic SMZ 168 stereo microscope and were made into slides mounted in water by using a syringe needle. Morphological characters photographed by using a Carl Zeiss stereo microscope fitted with an AxioCam ERC 5S camera and a Nikon ECLIPSE 80i compound microscope fitted with a Canon EOS 600D digital camera. Measurements were carried out by Tarosoft Image Frame Work program v. 0.97 (Liu et al. 2010) based on the calibrations fitted with the microimaging system, and which was used to take the photos mentioned above. Photo plate was processed by using Adobe Photoshop CS6 Extended v. 13.0. Single spores were isolated by diluting spores into small amount of sterilized deionized water, and then sprinkled onto potato dextrose agar (PDA) medium using a sterile pipette. The PDA plates with the spore suspension were incubated at $25^{\circ} \mathrm{C}-28^{\circ} \mathrm{C}$. Germinating spores were observed the next day using Motic SMZ 168 stereo microscope, and transferred to a new PDA medium. Herbarium specimens of the new taxon were deposited at the herbaria of Mae Fah Luang University (MFLU), Chiang Rai, Thailand; Kunming Institute of Botany Academia Sinica (KUN), Kunming, China; the ex-type living culture is deposited in Mae Fah Luang University Culture Collection (MFLUCC). Index Fungorum number (2019) and Facesoffungi number (Jayasiri et al. 2015) are obtained and provided.

\section{DNA extraction, PCR amplification and sequencing}

Fungal mycelia were scraped from the margin of a colony on PDA incubated at $25^{\circ} \mathrm{C}-28^{\circ} \mathrm{C}$ for one month. Fungal genomic DNA was extracted by using the Ezup Column Fungi Genomic DNA Purification Kit (Sangon Biotech (Shanghai) Co., Ltd, China). Four genes were used for polymerase chain reaction (PCR) of the new collections: the nuclear rDNA operon spanning the 3' end of the 18S nrRNA gene, the large subunit of the nuclear ribosomal RNA genes (LSU), the small subunit of the nuclear ribosomal RNA (SSU), and the translation elongation factor 1-alpha $(T E F 1 \alpha)$ and the second largest subunit of RNA polymerase II (RPB2). The primers used were ITS5/ITS4 for ITS (White et al. 1990), LR0R/LR5 for LSU (Vilgalys \& Hester 1990), NS1/NS4 for SSU (White et al. 1990), EF1-983F/EF1-2218R for TEF1 $\alpha$ (Rehner \& Buckley 2005), and fRPB25F/fRPB2-7cR for RPB2 (Liu et al. 1999). The amplification reactions were performed in $25 \mu \mathrm{L}$ of PCR mixtures containing $9.5 \mu \mathrm{L} \mathrm{ddH}_{2} \mathrm{O}, 12.5 \mu \mathrm{L} 2 \times$ PCR MasterMix (BBI Life Sciences Corporation, Shanghai, China), $1 \mu \mathrm{L}$ DNA temple and $1 \mu \mathrm{L}$ of each primer. The PCR thermal cycle program for LSU, SSU and TEF $1 \alpha$ amplification were as follows: initial denaturing step of $94^{\circ} \mathrm{C}$ for $3 \mathrm{~min}$, followed by 40 cycles of denaturation at $94{ }^{\circ} \mathrm{C}$ for 45 seconds, annealing at $56{ }^{\circ} \mathrm{C}$ for 50 
seconds, elongation at $72{ }^{\circ} \mathrm{C}$ for $1 \mathrm{~min}$, and final extension at $72{ }^{\circ} \mathrm{C}$ for $10 \mathrm{~min}$. The PCR thermal cycle program for $R P B 2$ was followed as initially $95{ }^{\circ} \mathrm{C}$ for $5 \mathrm{~min}$, followed by 40 cycles of denaturation at $95{ }^{\circ} \mathrm{C}$ for $1 \mathrm{~min}$, annealing at $52{ }^{\circ} \mathrm{C}$ for $2 \mathrm{~min}$, elongation at $72{ }^{\circ} \mathrm{C}$ for 90 seconds, and final extension at $72{ }^{\circ} \mathrm{C}$ for $10 \mathrm{~min}$. Purification and sequencing of PCR products were carried out with primers mentioned above at Sangon Biotech (Shanghai) Co., Ltd, China.

\section{Phylogeny analyses}

Phylogenetic analysis was performed based on three gene regions: LSU, SSU and RPB2 (Machouart et al. 2014, Tibpromma et al. 2018). Sequences with the inclusion of reference taxa related to Sympoventuriaceae (Table 1) were downloaded from GenBank. Multiple sequences of each gene region were aligned by online version of MAFFT v.7 (http://mafft.cbrc.jp/alignment/server/) (Katoh \& Standley 2013), and then manually optimized using BioEdit v.7.0.9 (Hall 1999). A concatenated data set of LSU, SSU and RPB2 sequences were used for phylogenetic analyses. The alignment of multi-gene dataset used for phylogenetic analyses is deposited in TreeBASE under the submission number 24507.

A maximum likelihood (ML) analysis was performed at the CIPRES web portal (Miller et al. 2010) using RAxML v.7.2.8 as part of the "RAxML-HPC Blackbox (8.2.10)" tool (Stamatakis 2006, Stamatakis et al. 2008). A general time-reversible model (GTR) was applied with a discrete GAMMA distribution and four rate classes. Fifty thorough ML tree searches were carried out in RAxML v.7.2.7 under the same model. One thousand non-parametric bootstrap iterations were run with the GTR model and a discrete gamma distribution. The resulting replicates were plotted onto the best scoring tree obtained previously.

Maximum parsimony (MP) analysis was performed using the heuristic search option with 1000 random taxa additions and tree bisection and reconnection (TBR) as the branch-swapping algorithm. All characters were unordered and of equally weight, gaps were treated as missing data. Maxtrees setting was 1000, and zero-length branches were collapsed, and all parsimonious trees were saved. Clade stability was assessed using a bootstrap (BT) analysis with 1000 replicates, each with 10 replicates of random stepwise addition of taxa (Hillis \& Bull 1993). Tree length [TL], Consistency index [CI], Retention index [RI], Rescaled consistency index [RC], Homoplasy index [HI] were calculated.

The Bayesian analysis was performed using PAUP v.4.0b10 (Swofford 2002) and MrBayes v.3.1.2 (Ronquist \& Huelsenbeck 2003). The best model for different genes partition in the concatenated data set was determined by MrModeltest 2.3 (Nylander 2004). Posterior probabilities (Rannala \& Yang 1996) were determined by Markov Chain Monte Carlo sampling (MCMC) (Larget \& Simon 1999) in MrBayes v.3.1.2. Four simultaneous Markov chains were run for 10 million generations and trees were sampled every 1000th generation, thus 10,000 trees were obtained. The suitable burn-in phases were determined by inspecting likelihoods and parameters in Tracer version 1.6 (Rambaut et al. 2013). Based on the tracer analysis, the first 1,000 trees representing $10 \%$ were discarded as the burn-in phase in the analysis. The remaining trees were used to calculate posterior probabilities in the majority rule consensus tree (critical value for the topological convergence diagnostic set to 0.01). Phylogenetic tree was visualized by FigTree v.1.4.2 (Rambaut 2014). The new taxon was established based on recommendations outlined by Jeewon \& Hyde (2016).

\section{Results}

\section{Phylogeny}

The individual phylogenetic analyses based on LSU, SSU and RPB2 genes were carried out and yielded similar topologies. The alignments of each gene were combined to perform multi-gene phylogenetic analyses, resulting in a matrix of 23 taxa and 2976 characters (LSU: 865 bp; SSU: 1022 bp and RPB2: 1089 bp) including gaps. RAxML, MP and Bayesian analyses were conducted and resulted in generally congruent topologies. The best scoring RAxML tree (Fig. 1) with a final 
optimization likelihood value of -12059.011217 . The matrix had 876 distinct alignment patterns, with $44.63 \%$ undetermined characters and gaps. Estimated base frequencies were as follows: $\mathrm{A}=$ $0.255690, \mathrm{C}=0.224381, \mathrm{G}=0.291544, \mathrm{~T}=0.228385$; substitution rates $\mathrm{AC}=1.261200, \mathrm{AG}=$ 2.964321, $\mathrm{AT}=1.535962, \mathrm{CG}=1.214748, \mathrm{CT}=6.758988, \mathrm{GT}=1.000000$; gamma distribution shape parameter $\alpha=0.511302$. Maximum parsimony analyses indicated that 2,063 characters were constant, 278 variable characters parsimony uninformative and 635 characters are parsimonyinformative. A heuristic search yield two equally most parsimonious trees ( $\mathrm{TL}=1777, \mathrm{CI}=0.732$, $\mathrm{RI}=0.699, \mathrm{RC}=0.512, \mathrm{HI}=0.268)$. The best-fit model of $\mathrm{GTR}+\mathrm{I}+\mathrm{G}$ was selected by Akaike information criterion (AIC) in Mrmodeltest and used for Bayesian settings.

All genera of Sympoventuriaceae, including the type species of Venturiaceae, were selected to represent taxa in the order Venturiales. The resulting tree (Fig. 1) is congruent with topologies from previous studies (Zhang et al. 2011, Machouart et al. 2014, Boonmee et al. 2014, Johnston \& Park 2016, Tibpromma et al. 2018), and the genus Yunnanomyces close to several fusicladium-like taxa nested in Sympoventuriaceae. In this study, the new isolates of Yunnanomyces phoenicis clustered with $Y$. pandanicola and formed a well-supported clade.

Table 1 Taxa used in this study and their GenBank accession numbers. The new generated sequences are indicated in bold.

\begin{tabular}{|c|c|c|c|c|c|}
\hline \multirow[t]{2}{*}{ Taxa } & \multirow[t]{2}{*}{ Strains } & \multicolumn{3}{|c|}{ GenBank Accession numbers } & \multirow[t]{2}{*}{ References } \\
\hline & & LSU & SSU & RPB2 & \\
\hline $\begin{array}{l}\text { Clavatispora } \\
\text { thailandiaca }\end{array}$ & $\begin{array}{l}\text { MFLUCC } \\
100107\end{array}$ & KF770458 & - & - & $\begin{array}{l}\text { Boonmee et al. } \\
2014\end{array}$ \\
\hline $\begin{array}{l}\text { Fusicladium } \\
\text { africanum }\end{array}$ & СРC 12828 & EU035423 & - & - & $\begin{array}{l}\text { Machouart et al. } \\
2014\end{array}$ \\
\hline Fusicladium cordae & CBS 675.82 & FN398149 & - & - & $\begin{array}{l}\text { Machouart et al. } \\
2014\end{array}$ \\
\hline $\begin{array}{l}\text { Fusicladium } \\
\text { intermedium }\end{array}$ & CBS 110746 & EU035432 & - & - & $\begin{array}{l}\text { Machouart et al. } \\
2014\end{array}$ \\
\hline Fusicladium pini & CBS 463.82 & EU035436 & - & - & $\begin{array}{l}\text { Machouart et al. } \\
2014\end{array}$ \\
\hline $\begin{array}{l}\text { Fusicladium } \\
\text { ramoconidii }\end{array}$ & CBS 462.82 & EU035439 & - & - & $\begin{array}{l}\text { Machouart et al. } \\
2014\end{array}$ \\
\hline $\begin{array}{l}\text { Fusicladium } \\
\text { sicilianum }\end{array}$ & CBS 105.85 & FN398150 & - & - & $\begin{array}{l}\text { Machouart et al. } \\
2014\end{array}$ \\
\hline $\begin{array}{l}\text { Mycosisymbrium } \\
\text { cirrhosum }\end{array}$ & MTCC12435 & KR259884 & KR259885 & KR349124 & $\begin{array}{l}\text { Pratibha \& } \\
\text { Prabhugaonkar } \\
2016\end{array}$ \\
\hline $\begin{array}{l}\text { Neocoleroa } \\
\text { metrosideri }\end{array}$ & ICMP 21139 & KU131677 & - & - & $\begin{array}{l}\text { Johnston \& } \\
\text { Park } 2016\end{array}$ \\
\hline Ochroconis constricta & CBS 211.53 & KF282653 & KF282671 & KF282686 & $\begin{array}{l}\text { Machouart et al. } \\
2014\end{array}$ \\
\hline $\begin{array}{l}\text { Phaeotrichum } \\
\text { benjaminii }\end{array}$ & CBS 541.72 & AY004340 & AY016348 & DQ677946 & Liu et al. 2017 \\
\hline $\begin{array}{l}\text { Scolecobasidium } \\
\text { excentricum }\end{array}$ & CBS 469.95 & KF282669 & KF282683 & - & $\begin{array}{l}\text { Machouart et al. } \\
2014\end{array}$ \\
\hline $\begin{array}{l}\text { Sympoventuria } \\
\text { capensis }\end{array}$ & CBS120136 & DQ885906 & - & - & $\begin{array}{l}\text { Crous et al. } \\
2007\end{array}$ \\
\hline $\begin{array}{l}\text { Sympoventuria } \\
\text { capensis }\end{array}$ & СРC12840 & DQ885904 & - & - & $\begin{array}{l}\text { Crous et al. } \\
2007\end{array}$ \\
\hline $\begin{array}{l}\text { Trichodelitschia } \\
\text { bisporula }\end{array}$ & CBS 262.69 & GU348996 & GU349000 & GU371802 & Liu et al. 2017 \\
\hline Venturia inaequalis & CBS 594.70 & GU301879 & GU296205 & - & $\begin{array}{l}\text { Zhang et al. } \\
2011\end{array}$ \\
\hline
\end{tabular}


Table 1 Continued.

\begin{tabular}{|c|c|c|c|c|c|}
\hline \multirow[t]{2}{*}{ Taxa } & \multirow[t]{2}{*}{ Strains } & \multicolumn{3}{|c|}{ GenBank Accession numbers } & \multirow[t]{2}{*}{ References } \\
\hline & & LSU & SSU & RPB2 & \\
\hline Venturia inaequalis & CBS 815.69 & GU301878 & GU296204 & _- & $\begin{array}{l}\text { Zhang et al. } \\
2011\end{array}$ \\
\hline Veronaeopsis simplex & CBS 588.66 & EU041877 & _ & _ & $\begin{array}{l}\text { Machouart et al. } \\
2014\end{array}$ \\
\hline Verruconis gallopava & CBS 118.91 & KF282655 & KF282673 & KF282688 & $\begin{array}{l}\text { Machouart et al. } \\
2014\end{array}$ \\
\hline Verruconis gallopava & CBS 437.64 & KF282656 & KF282674 & KF282689 & $\begin{array}{l}\text { Samerpitak et } \\
\text { al. } 2014\end{array}$ \\
\hline $\begin{array}{l}\text { Yunnanomyces } \\
\text { pandanicola }\end{array}$ & $\begin{array}{l}\text { MFLUCC 17- } \\
2260\end{array}$ & MH376743 & MH388333 & MH412736 & $\begin{array}{l}\text { Tibpromma et } \\
\text { al. } 2018\end{array}$ \\
\hline $\begin{array}{l}\text { Yunnanomyces } \\
\text { phoenicis }\end{array}$ & $\begin{array}{l}\text { MFLUCC } \\
19-0253\end{array}$ & MK976737 & МК976739 & MK986483 & This study \\
\hline $\begin{array}{l}\text { Yunnanomyces } \\
\text { phoenicis }\end{array}$ & $\begin{array}{l}\text { MFLUCC } \\
19-0254\end{array}$ & MK976738 & MK976740 & MK986484 & This study \\
\hline
\end{tabular}

Abbreviations: CBS: Centraalbureau voor Schimmelcultures, Utrecht, The Netherlands; CPC: Collection of Pedro Crous housed at CBS; ICMP: International Collection of Microorganisms from Plants, Auckland, New Zealand. MFLUCC: Mae Fah Luang University Culture Collection, Chiang Rai, Thailand; MTCC: Microbial type culture collection, Institute of Microbial Technology, Chandigarh, India.

Note: Additional sequences for the new taxa in this study are provided as follows: MFLUCC 190253 (TEF1 $\alpha=$ MK986485); MFLUCC 19-0254 (TEF1 $\alpha=$ MK986486).

\section{Taxonomy}

Yunnanomyces phoenicis S.N. Zhang \& J.K. Liu, sp. nov.

Fig. 2

Index Fungorum number: IF556745; Facesoffungi number: FoF06149

Etymology - referring to the host on which the fungus was collected.

Saprobic on rachides and leaves of palms. Sexual morph: Undetermined. Asexual morph: Hyphomycetous. Colonies scattered, granular, black, glistening, punctiform distributed on the substrate. Mycelium mostly immersed in the substrate, composed of branched, septate, subhyaline to pale brown, smooth hyphae. Conidiophores semi-macronematous, reduced to conidiogenous cells, subhyaline to pale brown, smooth, thin-walled. Conidiogenous cells $0.7-1.2 \mu \mathrm{m}$, integrated, determinate, holoblastic, monoblastic, terminal, cylindrical, subhyaline to pale brown. Conidia (14)18-34 × (8.5-)12-22 ( $\bar{x}=24.6 \times 17.7 \mu \mathrm{m}, \mathrm{n}=30)$, acrogenous, solitary, globose to broadly ellipsoidal, muriform, brown and hyaline immature, thick-walled. The number of cells per conidium varies from 10-30, apical row with 1-3 cells.

Culture characteristics - Colonies growing well on PDA, and attaining a diameter of $22 \mathrm{~mm}$ after 21 days at $25^{\circ} \mathrm{C}$, circular, flat, velvety, with brown filamentous margin, obverse grey-green to brown, reverse dark brown. Mycelium hyaline to brown, septate, branched. Conidial sporulation was apparent in culture. Conidia in culture are slightly larger than on palm substrate, 17-35 $\times$ $12-24(\bar{x}=27.8 \times 19.4 \mu \mathrm{m}, \mathrm{n}=65)$.

Material examined - Thailand, Ranong, Ngao Mangrove Forest Research Center, on fallen rachides and leaves of Phoenix paludosa Roxb. (Arecaceae), 7 December 2016, S.N. Zhang, SNT72 (MFLU 19-0811, holotype; HKAS 105456, isotype), ex-type living culture: MFLUCC 190253. Ibid., Chanthaburi, Amphoe Khlung, Tambon Wan Yao, attached on leaf litter of Phoenix paludosa, 12 ${ }^{\circ} 26^{\prime} 43^{\prime \prime} \mathrm{N}, 102^{\circ} 15^{\prime} 47^{\prime \prime}$ E, 0m Elevation, 25 April 2017, S.N. Zhang, SNT158 (MFLU 19-0814 = HKAS 105478, paratype), living culture MFLUCC 19-0254.

Notes - Muriform ascospores or conidia are common in Ascomycota especially in Dothideomycetes, but rare in the family Sympoventuriaceae. The genus Yunnanomyces was 
introduced by Tibpromma et al. (2018) as a monotypic genus with Y. pandanicola as the type species. Herein we introduce a second Yunnanomyces species. Yunnanomyces phoenicis resembles $Y$. pandanicola in the globose to broadly ellipsoidal, muriform conidia. But it differs from $Y$. pandanicola in its semi-macronematous conidiophores, reduced to conidiogenous cells and bearing relatively larger brown conidia. The phylogenetic results showed that the isolates of Yunnanomyces phoenicis clustered together with $Y$. pandanicola and formed a monophyletic clade which represents a distinct species from $Y$. pandanicola (Fig. 1). In addition, to further justify the establishment, the single gene region comparison (Jeewon \& Hyde 2016) was carried out between these two species, there are 35 nucleotide substitutions (4.32\%) at specific positions in total 810 base pair of LSU, 23 nucleotide substitutions (2.33\%) at specific positions and six gaps in total 986 base pair of SSU, and $25.34 \%$ nucleotide substitutions in RPB2 gene region.

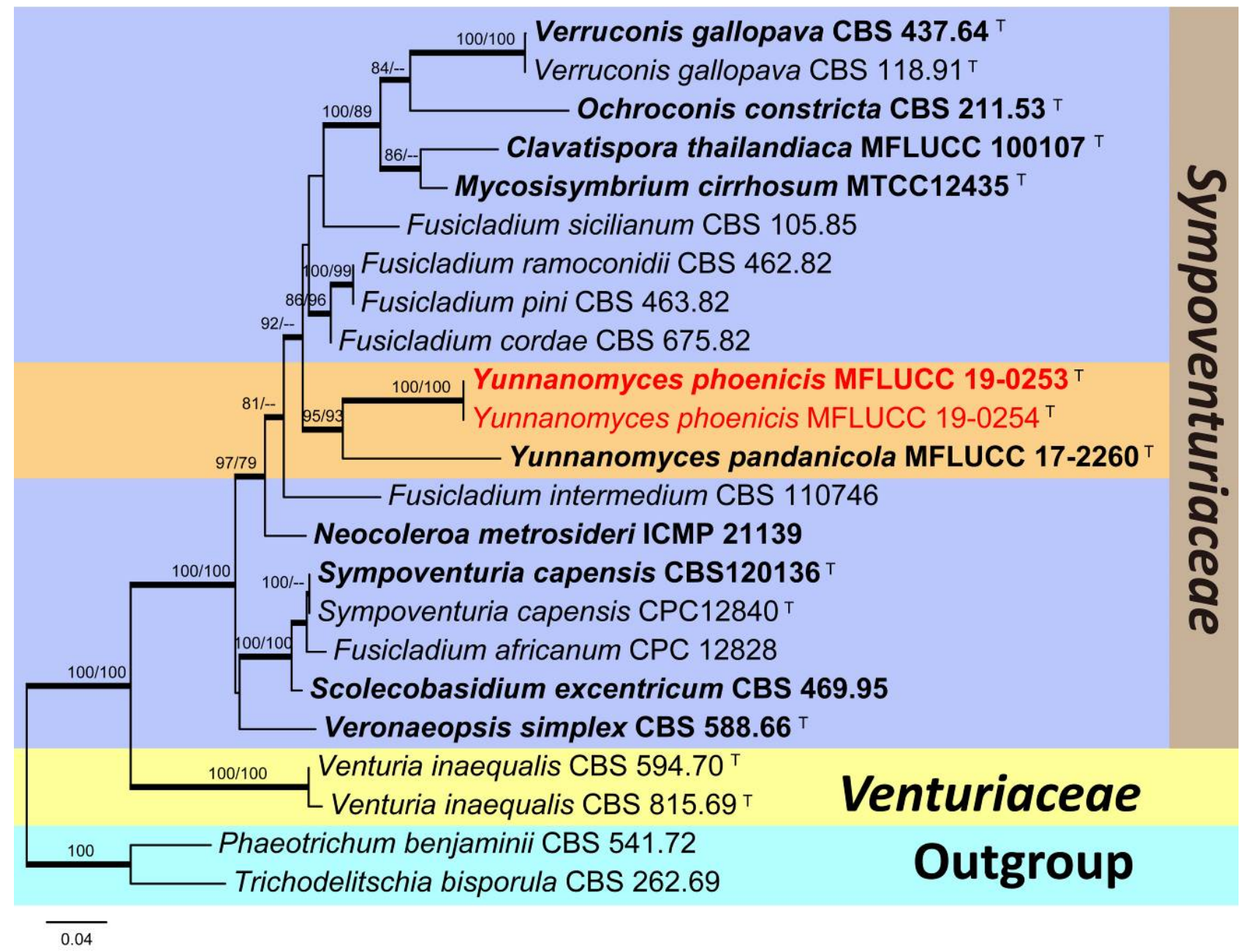

Fig. 1 - RAxML tree of representatives in Venturiales based on analysis of LSU, SSU and RPB2 gene region sequences data. Bootstrap values for ML and MP equal to or greater than 75 are placed (ML/MP) above the branches respectively. Branches with Bayesian posterior probabilities (PP) from MCMC analysis equal or greater than 0.95 are in bold. The type species are indicated with superscript ${ }^{\mathrm{T}}$ and ex-type strains are in bold. New generated sequences are indicated in red. The tree is rooted with Phaeotrichum benjaminii (CBS 541.72) and Trichodelitschia bisporula (CBS 262.69). 

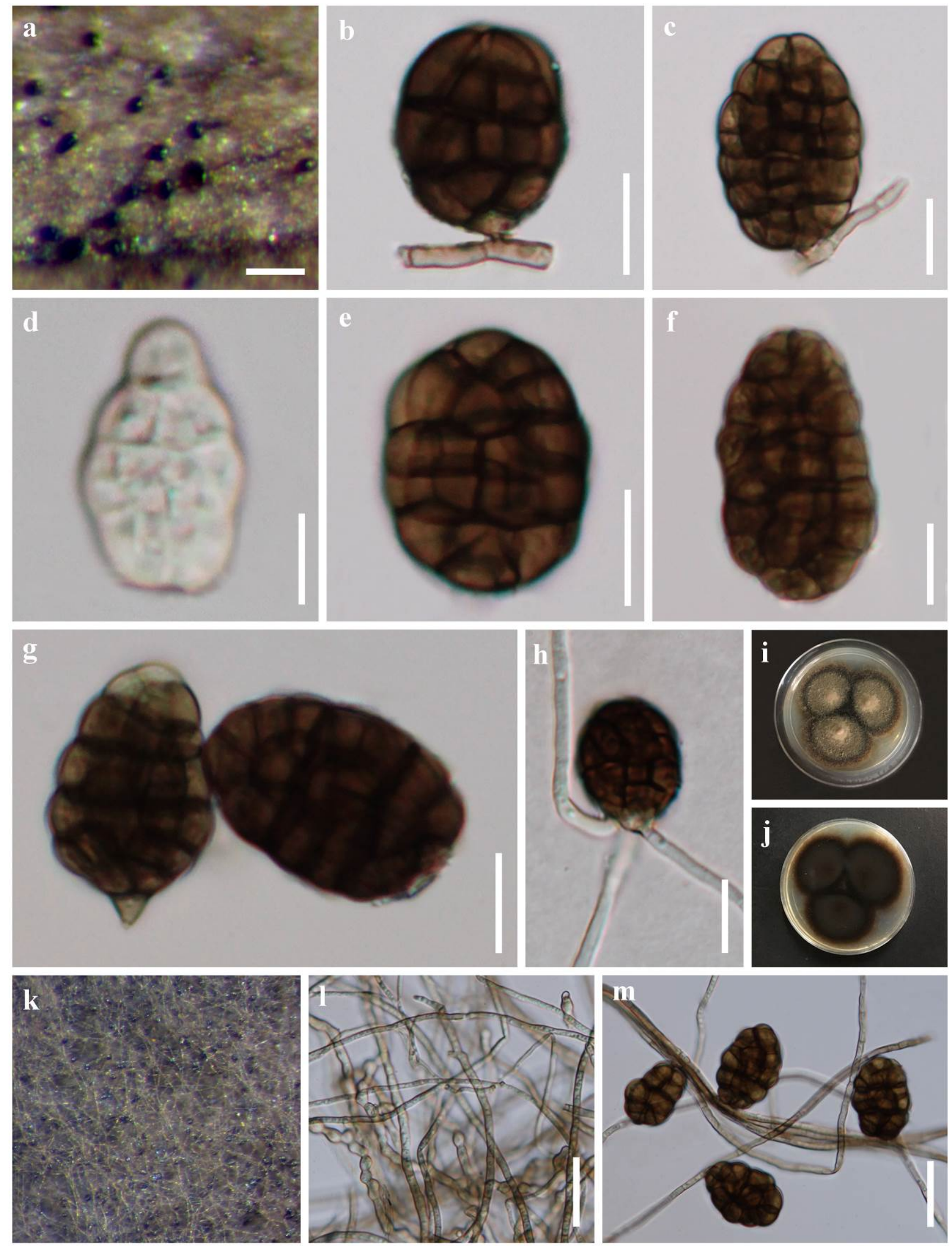

Fig. 2 - Yunnanomyces phoenicis (MFLU 19-0811, holotype). a Colonies on host substrate. b,c Conidiogenous cells developing conidia. d Hyaline, immature conidium. e-g Mature conidia. h Germinating conidium. i-j Culture on PDA. k-m Mycelium and sporulation in culture. Scale Bars: $\mathrm{a}=50 \mu \mathrm{m}, \mathrm{b}, \mathrm{c}, \mathrm{e}-\mathrm{h}=10 \mu \mathrm{m}, \mathrm{d}=5 \mu \mathrm{m}, \mathrm{l}-\mathrm{m}=20 \mu \mathrm{m}$. 


\section{Acknowledgements}

We are grateful to the grant of Thailand Research Fund for supporting collection and research facilities (Grant No. RSA5980068). Jian-Kui Liu thanks the National Natural Science Foundation of China (NSFC 31600032) and Science and Technology Foundation of Guizhou Province (LH [2015]7061). E.B. Gareth Jones is supported by the Distinguished Scientist Fellowship Program (DSFP), King Saud University, Kingdom of Saudi Arabia. The staffs of Ngao Mangrove Forest Research Center are thanked for their assistance in sample collection.

\section{References}

Arzanlou M, Groenewald JZ, Games W, Braun U et al. 2007 - Phylogenetic and morphotaxonomic revision of Ramichloridium and allied genera. Studies in Mycology 58, 57-93.

Boonmee S, Bhat JD, Maharachchikumbura SSN, Hyde KD. 2014 - Clavatispora thailandica gen. et sp. nov., a novel taxon of Venturiales (Dothideomycetes) from Thailand. Phytotaxa 176, 092-101.

Crous PW, Mohammed C, Glen M, Verkley GJM, Groenewald JZ. 2007 - Eucalyptus microfungi known from culture. 3. Eucasphaeria and Sympoventuria genera nova, and new species of Furcaspora, Harknessia, Heteroconium and Phacidiella. Fungal Diversity 25, 19-36.

Hall TA. 1999 - BioEdit: a user-friendly biological sequence alignment editor and analysis program for Windows 95/98/NT. Nucleic Acids Symposium Series 41, 95-98.

Hillis DM, Bull JJ. 1993 - An empirical test of bootstrapping as a method for assessing confidence in phylogenetic analysis. Systematic Biology 42, 182-192.

Hyde KD, Jones EBG, Liu JK, Ariyawansa H et al. 2013 - Families of Dothideomycetes. Fungal Diversity 63, 1-313.

Jayasiri SC, Hyde KD, Ariyawansa H, Bhat DJ et al. 2015 - The Faces of Fungi database: fungal names linked with morphology, phylogeny and human impacts. Fungal Diversity 74, 3-18.

Jeewon R, Hyde KD. 2016 - Establishing species boundaries and new taxa among fungi: recommendations to resolve taxonomic ambiguities. Mycosphere 7, 1669-1677.

Johnston PR, Park D. 2016 - Neocoleroa metrosideri sp. nov. (Sympoventuriaceae, Venturiales). Phytotaxa 253, 214-218.

Katoh K, Standley DM. 2013 - MAFFT multiple sequence alignment software version 7: improvements in performance and usability. Molecular Biology and Evolution 30, 772-780.

Konta S, Hongsanan S, Phillips AJL, Jones EBG et al. 2016a -Botryosphaeriaceae from palms in Thailand II - two new species of Neodeightonia, $N$. rattanica and $N$. rattanicola from Calamus (rattan palm). Mycosphere 7, 950-961.

Konta S, Hongsanan S, Tibpromma S, Thongbai B et al. 2016b - An advance in the endophyte story: Oxydothidaceae fam. nov. with six new species of Oxydothis. Mycosphere 7, 14251446.

Konta S, Phillips AJL, Bahkali AH, Jones EBG et al. 2016c - Botryosphaeriaceae from palms in Thailand - Barriopsis archontophoenicis sp. nov., from Archontophoenix alexandrae. Mycosphere (special issue), 921-932.

Konta S, Hongsanan S, Eungwanichayapant PD, Liu JK et al. 2017 - Leptosporella (Leptosporellaceae fam. nov.) and Linocarpon and Neolinocarpon (Linocarpaceae fam. nov.) are accommodated in Chaetosphaeriales. Mycosphere 8, 1943-1974.

Larget B, Simon DL. 1999 - Markov chain Monte Carlo algorithms for the Bayesian analysis of phylogenetic trees. Molecular Biology and Evolution 16, 750-759.

Liu JK, Chomnunti P, Cai L, Phookamsak R et al. 2010 - Phylogeny and morphology of Neodeightonia palmicola sp. nov. from palms. Sydowia 62, 261-276.

Liu JK, Hyde KD, Jeewon R, Phillips AJ et al. 2017 - Ranking higher taxa using divergence times: a case study in Dothideomycetes. Fungal Diversity 84, 75-99.

Liu YJ, Whelen S, Hall BD. 1999 - Phylogenetic relationships among ascomycetes: evidence from an RNA polymerse II subunit. Molecular Biology and Evolution 16, 1799-1808. 
Machouart M, Samerpitak K, de Hoog GS, Gueidan C. 2014 - A multigene phylogeny reveals that Ochroconis belongs to the family Sympoventuriaceae (Venturiales, Dothideomycetes). Fungal Diversity 65, 77-88.

Miller MA, Pfeiffer W, Schwartz T. 2010 - Creating the CIPRES Science Gateway for inference of large phylogenetic trees; Proceedings of the Gateway Computing Environments Workshop (GCE) 2010. New Orleans, Louisiana.

Nylander JAA. 2004 - MrModeltest v2. Program distributed by the author. Evolutionary Biology Centre, Uppsala University.

Pratibha J, Prabhugaonkar A. 2016 - Distribution and phylogeny of Mycosisymbrium cirrhosum. Mycosphere 7, 44-50.

Rambaut A. 2014 - FigTree 1.4.2. Available online: http://ree.bio.ed.ac.uk/software/figtree/

Rambaut A, Suchard M, Xie D, Drummond A. 2013 - Tracer version 1.6. Available online: http://tree.bio.ed.ac.uk/software/tracer/

Rannala B, Yang ZH. 1996 - Probability distribution of molecular evolutionary trees: a new method of phylogenetic inference. Journal of Molecular Evolution 43, 304-311.

Rehner SA, Buckley E. 2005 - A Beauveria phylogeny inferred from nuclear ITS and EF1- $\alpha$ sequences: evidence for cryptic diversification and links to Cordyceps teleomorphs. Mycologia 97, 84-98.

Ronquist F, Huelsenbeck JP. 2003 - MrBayes3: Bayesian phylogenetic inference under mixed models. Bioinformatics19, 1572-1574.

Samerpitak K, Van der Linde E, Choi HJ, Gerrits van den Ende AHG et al. 2014 - Taxonomy of Ochroconis, genus including opportunistic pathogens on humans and animals. Fungal Diversity 65, 89-126.

Stamatakis A. 2006 - RAxML-VI-HPC: maximum likelihood-based phylogenetic analyses with thousands of taxa and mixed models. Bioinformatics 22, 2688-2690.

Stamatakis A, Hoover P, Rougemont J. 2008 - A rapid bootstrap algorithm for the RAxML web servers. Systematic Biology 57, 758-771.

Swofford DL. 2002 - PAUP*. Phylogenetic analysis using parsimony (*and other methods). Version 4. Sinauer Associates, Sunderland, Massachusetts. USA.

Tibpromma S, Hyde KD, McKenzie EHC, Bhat DJ et al. 2018 - Fungal diversity notes 840-928: micro-fungi associated with Pandanaceae. Fungal Diversity 93, 1-160.

Vilgalys R, Hester M. 1990 - Rapid genetic identification and mapping of enzymatically amplified ribosomal DNA from several Cryptococcus species. Journal of Bacteriology 172, 4238-4246.

Wanasinghe DN, Jeewon R, Jones EBG, Boonmee S et al. 2018 - Novel palmicolous taxa within Pleosporales: multigene phylogeny and taxonomic circumscription. Mycological Progress 17, 571-590.

White TJ, Bruns T, Lee S, Taylor J. 1990 - Amplification and direct sequencing of fungal ribosomal RNA genes for phylogenetics. Pp 315-322 In: Innis MA, Gelfand DH, Sninsky JJ, White TJ (eds) PCR protocols: a guide to methods and applications. Academic Press, Inc., New York.

Zhang SN, Hyde KD, Jones EBG, Cheewangkoon R, Liu JK. 2018 - Acuminatispora palmarum gen. et sp. nov. from mangrove habitats. Mycological Progress 17, 1173-1188.

Zhang SN, Abdel-Wahab MA, Jones EBG, Hyde KD, Liu JK. 2019a - Additions to the genus Savoryella (Savoryellaceae), with the asexual morphs Savoryella nypae comb. nov. and $S$. sarushimana sp. nov. Phytotaxa (in press)

Zhang SN, Hyde KD, Jones EBG, Jeewon R, Cheewangkoon R, Liu JK. 2019b - Striatiguttulaceae, a new pleosporalean family to accommodate Longicorpus and Striatiguttula gen. nov. from palms. MycoKeys 49, 99-129.

Zhang Y, Crous PW, Schoch CL, Bahkali AH, Guo LD, Hyde KD. 2011 - A molecular, morphological and ecological re-appraisal of Venturiales - a new order of Dothideomycetes. Fungal Diversity 51, 249-277. 